\title{
The Transparency of Risk Information in Islamic Banks: The Role of Independent Director and Shariah Supervisory
}

\author{
Gusrianti $^{1}$, Evony Silvino Violita ${ }^{2}$ \\ \{gusriantigmn@gmail.com ${ }^{1}$, evony.silvino@gmail.com ${ }^{2}$ \} \\ Magister Science in Accounting, Faculty of Economics and Business, \\ Universitas Indonesia, Depok, Indonesia ${ }^{1,2}$
}

\begin{abstract}
This study aims to examine the effect of supervision carried out by independent director and Sharia Supervisory Board (SSB) to the transparency of risk information in Islamic banks. Data collection is carried out by analyzing the content of the annual reports of 30 Islamic banks in 2014-2017 using the transparency of risk information Index (TRII) of Islamic Banks. The result shows that the level of transparency of risk information in Islamic banks is still relatively low (59\%). Regression shows that the characteristics of SSB are positively related to the transparency of risk information on Islamic banks, while independent directors are not. This research shows that the oversight mechanism carried out by SSB is more effective in encouraging transparency of risk information of Islamic banks than independent directors. This research implies the importance of strengthening the role and position of the SSB in encouraging transparency of risk information in Islamic banks.
\end{abstract}

Keywords: Islamic banks, independent director, Shariah Supervisory Board (SSB) characteristics, transparency of risk information

\section{Introduction}

Transparency is a crucial issue for banks, especially after various crises such as the Asian crisis in 1997 [1] which placed banks as one of the parties blamed for being considered less transparent [2], [3]. Banks need to be transparent in presenting information to stakeholders, one of which is information about risk. Transparency of risk information is the provision of adequate, reliable, and relevant risk information to stakeholders so that stakeholders can assess risk profiles and risk management practices that can be used as considerations in allocating resources [4]. Risk information needs to be presented transparently, because the transparency of the company's risk will make it easier for users to evaluate risk management carried out by the company [3].

Islamic accounting strongly supports transparency in business activities [5], [6], so banks and Islamic financial institutions have to adopt transparency, disclosure, and documentation more than conventional banks [7]. Transparency of risk information means implementing ethical values in Islam originating from the Qur'an and the Sunnah that upholds accountability and transparency. In addition to being subject to sharia rules, Islamic banks must also comply with the regulations stipulated by regulators [8], in accordance with ethical rules and in line with general financial practices [9]. Thus, the demand for transparency of risk information in 
Islamic banks is greater than conventional banks because besides being regulated by sharia rules upholding accountability and transparency which requires the operation of Islamic banks to be in accordance with ethical rules, Islamic banks must also be in line with financial practices and products.

Risk is also one of the information needed by the main stakeholders of Islamic banks [10] because risk is forward-looking information, so banks are required to be more transparent by disclosing information that is sufficient, accurate, relevant and timely [2]. This aims to reduce and avoid information asymmetry between banks and stakeholders, especially customers who use profit sharing contracts when placing their funds in Islamic banks [11] and shareholders of Islamic bank. Furthermore, providing risk information will provide stakeholders a clearer understanding of the risks faced by banks and how the bank's strategy in managing these risks [11].

This study aims to examine the influence of independent director (this term is interchangeable with independent commissioners in 2-tier system) and the characteristics of Shariah Supervisory Board (SSB) on transparency of risk information on Islamic banks. Independent director is measured by the proportion of independent director in Islamic banks and the characteristics of SSB are measured by the Islamic Corporate Governance (ICG) Index which is a combination of various SSB characteristics.

A board of directors is a governance organ who supervises and provides direction to the directors in managing the company, but cannot participate in making decisions related to the company's operations. An independent director is member of board of directors who has no affiliation with a member of the board of directors, other board members, SSB, controlling shareholders and is not involved in business relationships and/ or other relationships that can influence their decision to act independently and/ or in the interests of the company [12]. Fama and Jensen [13] said that the existence of an independent director will increase control within the company and limit oportunistics behavior of management. Independent directors have an important contribution in improving managerial quality and decisions [11] because supervision by the board of director influences decisions made by management, including determining the transparency of information that will be carried out by the company.

SSB is a characteristic of governance in Islamic banks whose duty is to oversee the operational activities and products of Islamic banks so that they are in accordance with sharia principles [14]. The important role of SSB gives them an equal position equal with the board of directors. Similar to companies and conventional banking, good governance is an important mechanism that must be implemented by Islamic banks, so Islamic banks operate in accordance with sharia principles, one of which fulfills the principle of transparency [15].

To the best of our knowledge, research on transparency of risk information is more frequently done on companies and banks in conventional context such as Lajili and Zéghal [16]; Linsley, et al. [17]; Naser, et al. [18]; ElKelish and Hassan [19]; Hassan [20]; dan A1Shammari [21], so the further research in Islamic banks needs to be done. This is also due to research related to Islamic bank transparency looking more on corporate governance [22]-[25] and disclosure of corporate social responsibility in Islamic banks [26], [27]. The research that examine at how transparency of risk information in Islamic banks is still descriptive and qualitative in form, such as Ismail, et al. [3] who examine risk management information disclosure in Islamic financial institutions in Malaysia before, during and after the financial crisis in 2008. The research of Neifar and Jarboui [11] examines factors that influence disclosure of operational risk in Islamic banks. It can be concluded that research on transparency of risk information in Islamic banks is still at an exploratory stage and needs to be further developed. 
This study seeks to address some of the limitations of previous research by providing several contributions. First, this study uses a Islamic bank risk information transparency index developed by [4] specifically for Islamic banks so that it considers the types of risks and information needs of the main stakeholders of Islamic banks. Second, this study examines how the influence of independent director and the characteristics of SSB on the transparency of risk information in Islamic banks. This study will enrich the literature on the transparency of risk information in Islamic banks, not only the description of the level of transparency of risk information for Islamic banks, but also look at the factors that affect transparency. Third, this research is conducted on Islamic banks operating in a top-10-country that has the most developed Islamic finance market in the world according to the Islamic Finance Development Indicator (IFDI) issued by Thomson Reuters 2015 and 2016. This is done to find out how transparency of risk information in countries that have the most developed Islamic finance market compared to other countries in the world. This research will provide new insights on the transparency of risk information for Islamic banks outside the Gulf Region Cooperation Council (GCC), Middle East and North Africa (MENA), and South Asia that has been carried out by Bukair and Rahma [28] dan Farook, et al. [29].

\section{Literature Review}

\subsection{Agency Problem}

According to agency theory, a company is a nexus of contracts between the owners of economic resources (principals) and managers (agents) who manage and control these resources [30]. The resource owner delegates authority to the manager (agent) to manage these resources in accordance with the interests of the fund owner. In this agency relationship, a problem arises called agency conflict because of the information asymmetry between the principal (owner) and the agent (management), where the agent generally has more information about the actual financial position and operating position of the entity than the principal [13]. In addition, this theory arises from a conflict of interest due to differences in objectives, where management does not always act in accordance with what the owner expects.

In the context of Islamic banks, there are 2 types of principals, namely shareholders and owners of profit-sharing investment account (PSIA). With the existence of these 2 types of principals, the agency relationship found in Islamic banks is not only between managers (agents) and shareholders (principals), but also between managers (agents) and owners of profit-sharing funds (principals). The owners of the fund (shahibul maal) have a position similar to shareholders because they are involved in business cooperation with Islamic banks [31]. This causes the issue related to agency problems in Islamic banks not only related to the separation of ownership and control from the shareholders' side, but also from the separation of cash flow rights and control from the depositor's side and the holder of profit-sharing investment account [32]. Thus, agency problems found in Islamic banks are more complex than those experienced by conventional banks.

In an effort to minimize agency conflict arises costs called agency cost [30]. One form of agency cost is the cost of supervision used to monitor the agent in order to acts in accordance with the interests of the principal and reports all company activities accurately. Reporting information related to the activities of this company must meet the information needs of 
stakeholders, at least the main stakeholders of the company. Therefore, Islamic banks need to disclose information related to company risk so that stakeholders can get the information needed to assess the level of transparency of risk information on Islamic banks.

\subsection{Risk of Islamic Banks}

Wahyudi, et al. [33] define risk as a consequence of a choice that contains uncertainty with the potential to produce something unwanted or negative consequences experienced by decision makers. Risk in Islamic banks can be grouped into financing risk, liquidity risk, market risk, operational risk, rate of return risk, and displaced commercial risk [34]. Financing risk is a risk that arises when a customer or other party fails to fulfill its obligations towards an Islamic bank based on the agreed upon contract [33]. This risk applies to sharia financial institutions that manage the exposure of financing receivables and leases (for example in murabahah, diminishing musyarakah, and ijarah) and work capital financing projects/transactions (such as in salam, istishna and mudharabah contracts). The failure to fulfill this payment obligation can be caused by the inability of customers (partners) to pay or even the unwillingness of customers to pay.

Liquidity risk is a risk that arises from the potential inability of Islamic banks to fulfill obligations that have reached the due date [33] or to fund an increase in assets without incurring unacceptable costs or losses [34]. This liquidity risk occurs because of temporary imbalances between the source of funds owned by the bank, third party funds, and financing contracts given by the bank to the debtor. Regarding the financing provided, liquidity risk occurs when financing provided by banks to third parties/customers often experience defaults or accept returns that are not as expected.

Market risk is the risk that occurs due to adverse market movements, namely fluctuations in the value of instruments that can be traded and marketed or a decrease in value of stock prices, sukuk prices, commodity prices, and foreign exchange rates of various assets stored in portfolio by Islamic banks that can cause actual losses [33], [34]. This risk occurs when a bank has assets for the purpose of being resold at certain times in the future, not held to maturity [33]. These market risks include exchange rate, commodity price risk, equity price risk, and benchmark rate risk.

Operational risk is the risk of loss caused by inadequate company internal control systems, internal process failures, human errors, system failures, and/ or the possibility of several external events that could disrupt bank operations [33]. Non-compliance with sharia (compliance risk) which is the failure of Islamic bank banks in complying with sharia rules and principles and failure in fiduciary responsibility towards different fund providers is also included in operational risk [34]. In addition, business risk (busisness risk) is also included in the risk of operating risk categories.

The rate of return risk arises because of a change in the rate of return paid by Islamic banks to its customers which causes changes in customer behavior[33]. It will happen when there is a difference between the rate of return expected by the customer (fund owner, investment account holder) that places funds in Islamic banks different from the rate of return provided by Islamic banks to customers. When the rate of return provided by Islamic banks do not meet customer expectations, this will trigger transactional customers to transfer their funds to other banks, either to other Islamic banks or even to conventional banks [33].

Displaced commercial risk (DCR) refers to the amount of risk transferred to shareholders to protect the owner of the fund (IAH) from bearing some or all of the risks they face according to the contract in the mudharabah contracts. Risk sharing is achieved by forming 
and using storm reserves such as profit equalization reserves (PER) and by adjusting bank profit sharing (mudarib) to facilitate returns paid to fund owners from exposure to aggregate returns on volatility arising from banking risk. With this, it will allow payment of competitive returns on the market.

\subsection{The Transparency of Risk in Islamic Bank}

There are various views in defining transparency. Transparency is a tool that can be used by market participants to obtain information needed in order to allocate resources [8]. AAOIFI [10] sees transparency as an activity or condition, namely providing sufficient, reliable, and relevant information for stakeholders. Whereas BCBS [35] specifically states that in the banking context, transparency is the provision of timely and reliable information that enables stakeholders to assess bank performance and health, business activities, and risk profiles and risk management practices carried out by banks. From these various views it can be concluded that transparency is the provision of sufficient, reliable, and relevant information for stakeholders to assess company performance and activities.

Companies are considered transparent when doing appropriate and adequate disclosures [10]. From the definition of transparency proposed by BCBS [35] it can be concluded that when the bank is transparent, stakeholders can not only assess the performance and business activities of Islamic banks but also can assess risk profiles and risk management practices carried out by banks. If it is associated with risk, the company is said to be transparent on its risks when it has provided risk information to stakeholders appropriately and adequately so that stakeholders can assess the business profile and risk management practices carried out by the company. Based on the above literature, this study defines transparency of risk information as providing adequate, reliable, and relevant risk information to stakeholders so that stakeholders can assess risk profiles and risk management practices that can be used as considerations in allocating resources.

\subsection{Prior Research and Hypotheses Development}

Independent Director and Transparency of Risk Information in Islamic Banks. Companies which has good corporate governance have effective oversight mechanisms for management behavior, so management seeks to act in accordance with the interests of shareholders because of the effective supervision by the board of director of the company. One aspect that will be considered by management is the information needs of shareholders who are the company's main stakeholders, so that the company will strive to be transparent by disclosing various information needed by stakeholders. Broader disclosures will make stakeholders understand information about how management manages the company [36]. Therefore, good corporate governance is a conducive corporate environment and encourages companies to be more transparent.

The existence of independent director in a company can improve control within the company and restrain management opportunism [13]. It means that independent director has an important contribution in improving managerial quality and decisions [11] because the supervision influences management decisions including in determining the transparency of information that will be carried out by the company. Ben-Amar and Boujenoui [37]; Bujaki and McConomy [38]; Parsa, et al. [39]; and Samaha, et al. [40] find that there is a positive relationship between the independence of the board of director and corporate governance reporting which is one type of information that needs to be disclosed by the company as a 
form of transparency to stakeholders. Other studies such as Chen and Jaggi [41] did not find that the independence of the board of director will increase the monitoring ability of the board of director, so that the presence of an independent board of commissioners does not affect the company's transparency in implementing the disclosure framework. Based on above description, the first hypothesis of this study is:

H1: There is a positive relationship between the independent board of commissioners and the transparency of risk information in Islamic banks

Sharia Supervisory Board (SSB) Characteristics and Transparency of Risk Information in Islamic Banks. Islamic banks have additional governance in the form of Islamic corporate governance carried out by the Sharia Supervisory Board (SSB). Islamic corporate governance is a mechanism for building and maintaining stakeholder trust [29]. SSB oversees the activities and operations of Islamic banks in accordance with sharia rules, one of which is to avoid the existence of gharar by increasing disclosure [23]. Therefore, the existence of SSB in Islamic banks will strengthen overall corporate governance.

Characteristics of SSB such as size of SSB, SSB cross-membership, and expertise of SSB can influence company transparency which can be seen from disclosures such as disclosure of corporate governance [23]. Theses characteristcs reflect the resources and capabilities possessed by SSB to carry out their duties in overseeing and ensuring sharia compliance aspects in Islamic banks. The many factors that are characteristic of SSB will influence how SSB performs its functions [42]. Companies with larger SSB sizes have more resources to supervise company activities, such as corporate reporting. Larger member will enable SSB to devide task dan delegate authority among SSB members [23] in carrying out tasks so that SSB monitoring capabilities will increase [42]. This makes SSB more focused in conducting reviews on the reporting carried out by the company so that it can be more transparent.

In non-sharia contexts, the size or number of supervisory boards is frequently associated with the level of disclosure made which will lead to corporate transparency. Husted and de Sousa-Filho [43] find that the size of the board of directors is positively related to Environmental, Social and Governance (ESG) disclosures in South American companies. Abeysekera [44] find that companies with larger member of board expressed more internal strategies and company resources to public companies in Kenya. On the other hand, Elgammal, et al. [45] find a negative relationship between the number of non-executive directors and risk disclosures in companies in Qatar. Raman and Bukair [46] find that SSB with more members could be more effective in monitoring the activities of Islamic banks related to social issues based on sharia principles and rules. In addition, Samaha, et al. [47] conducted a meta-analysis of previous studies and find that most studies conclude that board size is positively related to disclosure. Assuming there are the diversity of expertise, perspectives, and industry experience in the board, a larger size of the board is expected to increase the number of expertise due to a large number of human resources [48] that form corporate governance and conduct more in-depth review of corporate reporting corporate governance that will increase the effectiveness of the board which has implications for more disclosure [49] so that the company is more transparent [23]. In other words, the size of the SSB will affect the transparency of Islamic banks which can be seen from the level of disclosure made.

SSB Cross-membership is defined as the condition when a SSB member of an Islamic bank at the same time also serves as a member or chairman of the SSB in other Islamic financial institutions [22]. One of the causes of cross-membership is the need for human resources that are able to perform SSB functions well [50]. Like the board of directors, board 
expertise in a field is very much needed in carrying out tasks [51]. SSB must consist of members who understand Islamic principles and modern finance. Cross-membership will increase the effectiveness of SSB in carrying out its role due to expertise (Samra, 2016) and the status possessed [52] SSB as a supervisory board. SSB members who hold positions in several SSB will have more knowledge and experience, allowing SSB to make comparisons and determine the best Islamic corporate governance practices that can be carried out in Islamic banks [23], [42]. The experience and insights obtained in one of the Islamic banks can be combined with the insights gained from the position as SSB in other Islamic financial institutions. In addition, SSB members serving several SSB will also be involved in various discussions on the implementation of Islamic laws and rules so that they will enhance understanding of how the application of Islamic principles in corporate reporting [42]. Thus, cross-membership is an indication of the ability and experience that can be used more by SSB in carrying out their duties. This capability will increase the effectiveness of SSB in monitoring Islamic bank activities because SSB has a better understanding of sharia governance practices. This has been proven by Abdullah, et al. [22] who found that crossmembership had a positive effect on disclosure of information about SSB conducted by Islamic banks.

As aforementioned above, it can be seen that the most important characteristic in increasing corporate transparency is board expertise. In order to be able to carry out its role properly, SSB must consist of members who have an understanding of Islamic principles, financial expertise, accounting, banking, and economics [23], [50]. Improving the quality/ expertise of SSB will increase satisfaction of complaints [48] because SSB members with such expertise will better understand the importance of transparency to stakeholders by making more disclosures on Islamic bank reports [23]. Abdullah, et al. [22] found that expertise in the banking, economic, or financial fields of SSB members affected the disclosure of SSB by Islamic banks. Muda [53] conducts a study of the relationship between SSB expertise and disclosure in the Indonesian context and found that SSB expertise is positively related to disclosures in the SSB report. Thus, the next hypothesis is

H2: There is a positive relationship between the characteristics of SSB and the transparency of risk information in Islamic banks

\section{Methodology}

\subsection{Sample and Data}

This study is an empirical study conducted Islamic banks operating in 5 countries listed in a top-10-country that has the most developed Islamic finance market in the world according to the Islamic Finance Development Indicator (IFDI) report issued by Thomson Reuters in 2015 and 2016. Additional criteria used to determine the final sample of the study are (a) publish annual report for the year and ended in 31st December for period of 2014-2017, (b) separately present profit-sharing investment account liabilities and equities in financial statement, and (c) having complete financial and non-financial data needed in this study. According to [54] and [55], the Islamic banks met above criteria are operated in Indonesia (12 Islamic Banks), Bahrain (8 Islamic Banks), Qatar (4 Islamic Banks), Jordan (3 Islamic Banks), and Oman (3 Islamic Banks). The final sample of this study was 30 Islamic banks during the 4 years of the study period, 2014-2017. Research data are secondary data sourced from annual reports and 
official publications of Islamic banks. Data collection is carried out a content analysis on annual reports.

\subsection{Variable Definition \& Measurement}

The dependent variable of this study is the transparency of risk information on Islamic banks. Transparency of risk information on Islamic banks is the provision of adequate, reliable and relevant Islamic bank risk information to stakeholders so that stakeholders can assess risk profiles and risk management practices as considerations in allocating resources [4]. Transparency of Islamic bank risk information is measured by the level of risk information disclosure carried out by Islamic banks to stakeholders, because the company is considered transparent when making appropriate and adequate disclosures [10]. Measurement of company transparency by looking at the level of disclosure made by the company has also been done in previous studies such as Patel, et al. [1]. The measurement of the dependent variable is carried out by analyzing content using the Islamic bank risk information transparency index developed by Gusrianti [4], the components can be seen in Appendix 1. To obtain the transparency value of Islamic bank risk information, scoring is done on items in the risk information transparency index Islamic Bank.

$$
\operatorname{TRII}_{\text {it }}=\frac{\sum \mathbf{D}_{\text {it }}}{\mathbf{n}}
$$

TRII : Transparency of Risk Information Index

$\sum D_{\text {it }} \quad$ : Disclosure skor of Islamic bank i year $\mathrm{t}$

$n \quad$ : Maximum disclosure score

The following is a measure of the independence of the supervisory board. The independent variable is the independent board of commissioners and SSB characteristics. Independent boards are measured by the proportion of independent commissioners in the company. The greater proportion of independent commissioners will ensure effectiveness in following up on company policy [56]. The following is a measure of the independence of the supervisory board:

Proportion of independent director (ID) $=\frac{\text { number of independen director }}{\text { total number of board of director }}$

The characteristics of SSB are measured using a score of Islamic governance which is a combination of several characteristics of the SSB measured by dummy variables. Measuring methods that combine the various characteristics of SSB into index to measure the monitoring function performed by SSB have been carried out by various previous researchers such as Farook, et al. [29], Abdullah, et al. [23], dan Maulana [57]. The greater the score, it is expected that the level of effectiveness of sharia governance will increase. Details of the score component of sharia governance are in Appendix 2.

The control variables used in this study are company size (natural logarithm of total assets), profitability (ROA), age of Islamic bank, adoption of AAOIFI standards, and per capita income. This research model is: 


$$
\begin{aligned}
\text { TRII }_{i t}=\beta_{0}+ & \beta_{1} \text { ID }_{\text {it }}+\beta_{2} \text { ICG }_{\text {it }}+\beta_{3} \text { LnTA }_{\text {it }}+\beta_{4} \text { ROA }_{\text {it }}+\beta_{5} \text { Age }_{\text {it }}+\beta_{6} \text { AAOIFI }_{\text {it }} \\
& +\beta_{7} \text { GDP }_{\text {it }}+\varepsilon_{\text {it }}
\end{aligned}
$$

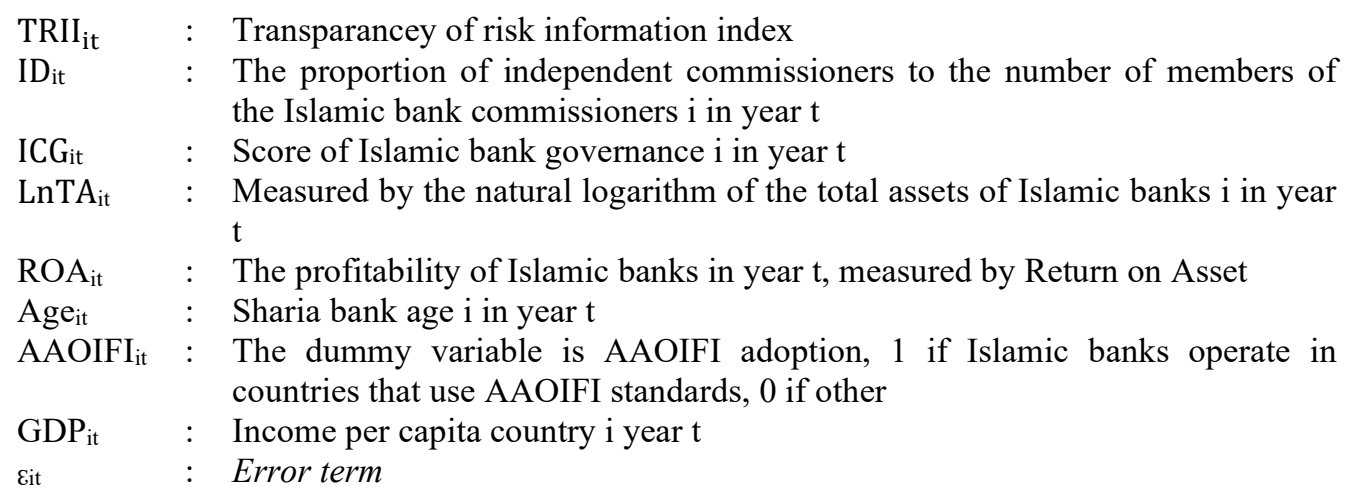

\subsection{Descriptive Statistics}

Descriptive statistics of research variables can be seen in Table 1. The average level of transparency of risk information for Islamic banks (TRII) is still quite low (59\%). The highest level of risk information transparency is $80.65 \%$ owned by Bahrain Islamic Bank (Bahrain) and the lowest is $30.11 \%$ owned by Bank Jabar Banten (Indonesia). This study found that the level of transparency of risk information on Islamic banks is quite diverse, in line with the findings [15]. 53.64\% of the board of director in Islamic banks are independent director. The average score of Islamic governance (ICG) is 4, meaning that most Islamic banks fulfill 4 characteristics of SSB.

Table 1. Descriptive statistics

\begin{tabular}{lcccccc}
\hline Variables & $\mathbf{N}$ & Mean & Median & Std. Dev & Min & Max \\
\hline TRII & 118 & 59.0579 & 55.375 & 12.50785 & 30,11 & 80.65 \\
ID & 118 & 53.6433 & 53.85 & 22.11085 & 0 & 100 \\
ICG & 118 & 3.983051 & 4 & .6534988 & 2 & 5 \\
TA (US\$) & 118 & $14,648 \mathrm{M}$ & $2,095 \mathrm{M}$ & $101,323 \mathrm{M}$ & $94 \mathrm{M}$ & $1,102,219 \mathrm{M}$ \\
ROA & 118 & 0.3125424 & 0.78 & 2.943879 & $-20,13$ & 5.67 \\
Age & 118 & 13.09322 & 9 & 10.35357 & 2 & 39 \\
AAOIFI & 118 & .5762712 & 1 & .489715 & 0 & 1 \\
GDP & 118 & $19,191.3$ & $15,102.38$ & $21,796.66$ & $3,334.55$ & $86,852.71$ \\
\hline
\end{tabular}

\section{Results}

\subsection{Independent Director and Transparency of Risk Information in Islamic Banks}

The regression results are presented in Table 2 . The coefficient of determination is $12.57 \%$, which means that $12.57 \%$ of changes in the dependent variable can be explained by independent variables, while $87.43 \%$ is explained by other variables not tested in this study. 
Prob (F-Statistic) 0.0006 means that simultaneously, the independent variable of this study influences the level of transparency of risk information on Islamic banks.

Table 2. Regression Result

\begin{tabular}{|c|c|c|c|c|c|}
\hline \multicolumn{6}{|c|}{$\mathrm{ITR}_{\mathrm{it}}=\underset{\varepsilon_{\mathrm{it}}}{\beta_{0}}+\beta_{1} \mathrm{ID}_{\mathrm{it}}+\beta_{2} \mathrm{ICG}_{\mathrm{it}}+\beta_{3} \mathrm{LNTA}_{\mathrm{it}}+\beta_{4} \mathrm{ROA}_{\mathrm{it}}+\beta_{5} \mathrm{Age}_{\mathrm{it}}+\beta_{6} \mathrm{AAOIFI}_{\mathrm{it}}+\beta_{7} G D P_{i t}+$} \\
\hline ITR & Predict. & Coeff.. & t-stat & P-value & Sig. \\
\hline ID & $\mathbf{H}_{1}:+$ & 0.004179 & 0.00 & 0,998 & \\
\hline ICG & $\mathbf{H}_{2}:+$ & 1.622557 & 3.01 & 0,003 & $* * *$ \\
\hline LnTA & + & -.154532 & -2.73 & 0,006 & $* * *$ \\
\hline ROA & + & -.154532 & -1.39 & 0,166 & $*$ \\
\hline Age & + & 0.1130009 & -0.40 & 0,690 & \\
\hline AAOIFI & + & 10.16125 & 2.31 & 0,021 & $* * *$ \\
\hline GDP & + & .0000316 & 0.73 & 0,463 & \\
\hline Cons & ? & 51.20061 & 13.75 & 0,000 & $* * *$ \\
\hline Year & \multicolumn{5}{|c|}{ Yes } \\
\hline Number of Observation & \multicolumn{5}{|c|}{118} \\
\hline Adjusted- $R^{2}$ & \multicolumn{5}{|c|}{0.1257} \\
\hline Prob (F-statistic) & \multicolumn{5}{|c|}{$0.0006^{* * *}$} \\
\hline
\end{tabular}

The regression test results indicate that the independent directors are not positively related to the transparency of risk information on Islamic banks. The results of this study reject hypothesis 1 that have been formulated previously. The results of this study indicate that the existence of an independent director does not have a significant effect on the transparency of the company's risk information. Thus, supervision by an independent director does not have a significant contribution in improving managerial quality and decisions in determining the breadth of the provision of transparent risk information carried out by Islamic banks to stakeholders.

The results of this study are in line with previous studies, namely Chen and Jaggi [41] who also did not find that the independence of the board of director can increase the monitoring ability of the board of director, so the presence of independent director does not have a significant effect on corporate transparency in implementing the disclosure framework. This can happen because in the context of Islamic banks, the role of monitoring is not only carried out by the board of director but also by SSB. Therefore, it is possible that the board of director does not pay too much attention to the transparency of risk information to stakeholders because this role is also expected to be carried out by the SSB as a sharia governance mechanism in Islamic banks. The findings of this study are different from the findings of previous studies, such as Neifar and Jarboui [11] who find that independent director influence the provision of company operational risk information carried out by Islamic banks through voluntary disclosure.

\subsection{Sharia Supervisory Board (SSB) Characteristics and Transparency of Risk Information in Islamic Banks}

Table 2. shows that the characteristics of SSB are positively related to the transparency of risk information on Islamic banks. This means that the better the characteristics of SSB, as 
indicated by the high score of governance, the higher the transparency of the company's risk information. Thus, these results indicate that the characteristics of the SSB affect the level of transparency of risk information for Islamic banks.

Characteristics of SSB, for example SSB size, SSB cross-membership, and SSB expertise, reflect the resources and capabilities possessed by SSB to carry out tasks in overseeing sharia compliance aspects. With the existence of these three characteristics in a sharia governance index, this shows that the ability possessed by the SSB influences the effectiveness of SSB in carrying out its duties, especially related to corporate risk reporting activities, so that Islamic banks are more transparent in corporate risk reporting.

The findings of this study are in line with several previous studies related to the company's openness in providing information to stakeholders. Maulana [57] find that Islamic banks which have better SSB members, as indicated by higher sharia governance scores, revealed more Islamic Social Responsibility (ISR) information. Farook and Lanis [42] dan Farook, et al. [29] find that the mechanism of sharia governance in Islamic banks had an effect on the provision of information carried out by Islamic banks, particularly in the disclosure of information related to corporate social responsibility. Septyan [58] also find that the characteristics of the SSB influenced the openness of information provided by Islamic banks through disclosure. The findings of this study are also in line with more specific research related to the provision of information through the disclosure of corporate risk in Islamic banks conducted by Abdallah, et al. [59]. From this research, it is known that the disclosure of risk information carried out by Islamic banks is higher if the bank has high quality corporate governance. This means that Islamic corporate governance played by SSB on Islamic banks is an important governance in providing transparent risk information to Islamic banks.

This study find different results for two measures that measure the effect of corporate governance on the transparency of risk information on Islamic banks. The difference in the results of testing on hypothesis 1 which is related to governance in general (rejected) and hypothesis 2 related to Islamic corporate governance (accepted) shows that in Islamic banks, governance implemented by SSB is more effective than corporate governance by independent commissioners in providing transparent corporate risk information to sharia bank stakeholders. Thus, SSB is more influential on transparency of risk information in Islamic banks. These results indicate the importance of Islamic banks enhancing the monitoring mechanism through investment of resources in the SSB for example by holding training for SSB members to increase the trust of fund owners and the community.

\section{Conclusions}

This study find that the mechanism of Islamic corporate governance carried out by SSB effects the level of transparency of risk information in Islamic banks. On the other hand, this study finds that there is no relationship between supervision carried out by independent director on the transparency of risk information on Islamic banks. This shows that in the context of risk information transparency, SSB is more effective in carrying out its functions to encourage companies to be more transparent to stakeholders in reducing information asymetry between agents and principals. The results of this study are in accordance with agency theory that there is agency conflict that must be monitored by using appropriate governance mechanisms in order to harmonize the interests of agents and principals, so that the existing information asymmetry can be reduced. 
This research implies the importance of strengthening the role and position of the SSB in encouraging transparency of risk information in Islamic banks, especially in Indonesia due to its development of islamic banking and finance is still in infancy level compare to other countries in this study. Future research can study the level of transparency of risk information in Islamic bank using more comprehensive and wider sample, for example using 10 ten countries listed in 1st edition of Islamic Finance Development Indicator (IFDI) until 2018 edition. It will be interesting knowing dan comparing the level of transparency of risk information in Islamic banks year by year among that countries.

Acknowledgments. This research was supported by the Indonesia Endowment Fund for Education (LPDP) and Integrated Laboratory and Research Center (DRPM) of Universitas Indonesia. 


\section{References}

[1] S. A. Patel, A. Balic, and L. Bwakira, "Measuring transparency and disclosure at firm-level in emerging markets," Emerg. Mark. Rev., vol. 3, no. 4, pp. 325-337, 2002.

[2] N. Lahrech, A. Lahrech, and Y. Boulaksil, "Transparency and performance in Islamic banking: Implications on profit distribution," Int. J. Islam. Middle East. Financ. Manag., vol. 7, no. 1, pp. 61-88, 2014.

[3] R. Ismail, R. A. Rahman, and N. Ahmad, "Risk management disclosure in Malaysian Islamic financial institutions: pre-and post-financial crisis," J. Appl. Bus. Res., vol. 29, no. 2, pp. 419 431, 2013.

[4] Gusrianti, "Pengaruh dewan komisaris independen, karakteristik Dewan Pengawas Syariah dan pendanaan bagi hasil terhadap transparansi informasi risiko bank syariah," Universitas Indonesia, 2019.

[5] M. Bhatti and M. I. Bhatti, "Toward understanding Islamic corporate governance issues in Islamic finance," Asian Polit. Policy, vol. 2, no. 1, pp. 25-38, 2010.

[6] N. Baydoun and R. J. Willett, "Islamic corporate reports," Abacus A J. Accounting, Financ. Bus. Stud., vol. 26, no. 1, pp. 71-90, 2000.

[7] M. Ayub, Understanding Islamic Finance. West Sussex, England: John Wiley \& Sons, 2007.

[8] S. Archer, R. A. A. Karim, and T. Al-Deehani, "Financial contracting, governance structures and the accounting regulation of Islamic banks: an analysis in terms of agency theory and transaction cost economics," J. Manag. Gov., vol. 2, no. 2, pp. 149-170, 1998.

[9] I. B. S. Mahdi and M. B. Abbes., "Behavioral explanation for risk taking in Islamic and conventional banks," Res. Int. Bus. Financ., vol. 45, pp. 577-587, 2018.

[10] AAOIFI, Accounting, Auditing and Governance Standards for Islamic Financial Institutions. Manama, Bahrain, 2015.

[11] S. Neifar and A. Jarboui, "Corporate governance and operational risk voluntary disclosure: Evidence from Islamic banks,” Res. Int. Bus. Financ., vol. 46, pp. 43-54, 2018.

[12] KNKG, Panduan Umum Good Governance Bisnis Syariah. Jakarta, 2011.

[13] E. F. Fama and M. C. Jensen, "Separation of ownership and control," J. Law Econ., vol. 26, no. 2, pp. 301-325, 1983.

[14] M. S. Antonio, Bank Syariah: Dari Teori ke Praktik. Gema Insani, 2001.

[15] E. Smolo and A. Mirakhor, "The global financial crisis and its implications for the Islamic financial industry," Int. J. Islam. Middle East. Financ. Manag., vol. 3, no. 4, pp. 372-385, 2010.

[16] K. Lajili and D. Zéghal, "A content analysis of risk management disclosures in Canadian annual reports," Can. J. Adm. Sci., vol. 22, no. 2, pp. 125-142, 2005.

[17] P. M. Linsley, P. J. Shrives, and M. Crumpton, "Risk disclosure: An exploratory study of UK and Canadian banks," J. Bank. Regul., vol. 7, no. 3-4, p. 279, 2006.

[18] K. Naser, A. Al-Hussaini, D. Al-Kwari, and R. Nuseibeh, "Determinants of corporate social disclosure in developing countries: the case of Qatar," Adv. Int. Account., vol. 19, pp. 1-23, 2006.

[19] W. W. ElKelish and M. K. Hassan, "Organizational culture and corporate risk disclosure," Int. J. Commer. Manag., vol. 11, no. 1, pp. 1-17, 2014.

[20] M. K. Hassan, "Risk narrative disclosure strategies to enhance organizational legitimacy: Evidence from UAE financial institutions," Int. J. Discl. Gov., vol. 11, no. 1, pp. 1-17, 2014.

[21] B. Al-Shammari, "Kuwait corporate characteristics and level of risk disclosure: a content analysis approach," J. Contemp. Issues Bus. Res., vol. 3, no. 3, pp. 128-153, 2014.

[22] W. A. W. Abdullah, M. Percy, and J. Stewart, "Shari' ah disclosures in Malaysian and Indonesian Islamic banks: The Shari'ah governance system," J. Islam. Account. Bus. Res., vol. 4, no. 2, pp. 100-131, 2013.

[23] W. A. W. Abdullah, M. Percy, and J. Stewart, "Determinants of voluntary corporate governance disclosure: Evidence from Islamic banks in the Southeast Asian and the Gulf Cooperation Council regions," J. Contemp. Account. Econ., vol. 11, no. 3, pp. 262-279, 2015.

[24] R. Grassa and R. Chakroun, "Ownership structure, board's characteristics and corporate governance disclosure in GCC banks: what about Islamic banks?," Int. J. Accounting, Audit. 
Perform. Eval., vol. 12, no. 4, pp. 360-395, 2016.

[25] K. Samaha and K. Dahawy, "An empirical analysis of corporate governance structures and voluntary corporate disclosure in volatile capital markets: The Egyptian experience," Int. J. Accounting, Audit. Perform. Eval., vol. 7, no. 1-2, pp. 61-93, 2010.

[26] S. El-Halaby and K. Hussainey, "Determinants of compliance with AAOIFI standards by Islamic banks," Int. J. Islam. Middle East. Financ. Manag., vol. 9, no. 1, pp. 143-168, 2016.

[27] M. A. Khurshid, A. Al-Aali, A. A. Soliman, and S. M. Amin, "Developing an Islamic corporate social responsibility model (ICSR)," Compet. Rev., vol. 24, no. 4, pp. 258-274, 2014.

[28] A. A. Bukair and A. A. Rahma, "The effect of the board of directors' characteristics on corporate social responsibility disclosure by Islamic banks," J. Manag. Res., vol. 7, no. 2, pp. 506-519, 2015.

[29] S. Farook, M. K. Hassan, and R. Lanis, "Determinants of corporate social responsibility disclosure: The case of Islamic banks," J. Islam. Account. Bus. Res., vol. 2, no. 2, pp. 114-141, 2011.

[30] M. C. Jensen and W. H. Meckling, "Theory of the firm: Managerial behavior, agency costs and ownership structure," J. financ. econ., vol. 3, no. 4, pp. 305-360, 1976.

[31] D. Siswantoro, “A critique of Islamic banks' good corporate governance report in Indonesia," $J$. Islam. Bus. Manag., vol. 219, no. 1237, pp. 1-28, 2012.

[32] A. Safieddine, “A. Safieddine,” Corp. Gov. An Int. Rev., vol. 17, no. 2, pp. 142-158, 2009.

[33] I. Wahyudi, F. Rosmanita, M. B. Prasetyo, and N. I. S. Putri, Risk management for Islamic banks: Recent developments from Asia and the Middle East. John Wiley \& Sons, 2015.

[34] IFSB, Disclosure to promote transparency and market discipline for institutions offering Islamic financial service excluding Islamic insurance (takaful) institutions and Islamic mutual funds), Vol. 4. Kuala Lumpur: Islamic Financial Service Board, 2007.

[35] BCBS, Basel Committee on Banking Supervision, Basel. Switzerland, 1988.

[36] N. M. Ariffin, "Enhancing transparency and risk reporting in Islamic banks," University of Surrey Surrey, 2005.

[37] W. Ben-Amar and A. Boujenoui, "Factors explaining corporate governance disclosure quality: Canadian evidence," in Illinois International Accounting Symposium, 2007.

[38] M. Bujaki and B. J. McConomy, "Corporate governance: Factors influencing voluntary disclosure by publicly traded Canadian firms," Can. Account. Perspect., vol. 1, no. 2, pp. 105139, 2002.

[39] S. Parsa, G. Chong, and E. Isimoya, "Disclosure of governance information by small and medium-sized companies," Corp. Gov. Int. J. Bus. Soc., vol. 7, no. 5, pp. 635-648, 2007.

[40] K. Samaha, K. Dahawy, K. Hussainey, and P. Stapleton, "The extent of corporate governance disclosure and its determinants in a developing market: The case of Egypt," Adv. Account., vol. 28, no. 1, pp. 168-178, 2012.

[41] C. J. Chen and B. Jaggi, "Association between independent non-executive directors, family control and financial disclosures in Hong Kong," J. Account. Public Policy, vol. 19, no. 4-5, pp. 285-310, 2000.

[42] S. Farook and R. Lanis, "Banking on Islam? Determinants of corporate social responsibility disclosure," Islam. Econ. Financ., p. 217, 2007.

[43] B. W. Husted and J. M. de Sousa-Filho, "Board structure and environmental, social, and governance disclosure in Latin America," J. Bus. Res., vol. 102, pp. 220-227, 2019.

[44] I. Abeysekera, "The influence of board size on intellectual capital disclosure by Kenyan listed firms," J. Intellect. Cap., vol. 11, no. 4, pp. 504-518, 2010.

[45] M. M. Elgammal, K. Hussainey, and F. Ahmed, "Corporate governance and voluntary risk and forward-looking disclosures,” J. Appl. Account. Res., vol. 19, no. 4, pp. 592-607, 2018.

[46] A. A. Raman and A. A. Bukair, "The influence of the Shariah supervision board on corporate social responsibility disclosure by Islamic banks of Gulf Co-operation Council countries," Asian J. Bus. Account., vol. 6, no. 2, 2013.

[47] K. Samaha, H. Khlif, and K. Hussainey, "The impact of board and audit committee characteristics on voluntary disclosure: A meta-analysis," J. Int. Accounting, Audit. Tax., vol. 
24, pp. 13-28, 2015.

[48] R. L. Hidalgo, E. García-Meca, and I. Martínez, "Corporate governance and intellectual capital disclosure," J. Bus. Ethics, vol. 100, no. 3, pp. 483-495, 2011.

[49] J. L. Gandía, "Determinants of internet-based corporate governance disclosure by Spanish listed companies," Online Inf. Rev., vol. 32, no. 6, pp. 791-817, 2008.

[50] E. Samra, "Corporate governance in Islamic financial institutions," 2016.

[51] J. Oehmichen, S. Schrapp, and M. Wolff, "Who needs experts most? B oard industry expertise and strategic change-a contingency perspective," Strateg. Manag. J., vol. 38, no. 3, pp. 208230, 2017.

[52] P. G. Badolato, D. C. Donelson, and M. Ege, "Audit committee financial expertise and earnings management: The role of status," J. Account. Econ., vol. 58, no. 2-3, pp. 208-230, 2014.

[53] I. Muda, "The effect of supervisory board cross-membership and supervisory board members' expertise to the disclosure of supervisory board's report: empirical evidence from Indonesia," Eur. Res. Stud., vol. 20, no. 3A, p. 691, 2017.

[54] A. B. Suandi, "Classification of profit-sharing investment accounts: A survey of financial statements of Islamic banks in Asia," Int. J. Islam. Middle East. Financ. Manag., vol. 10, no. 3, pp. 351-370, 2017.

[55] AOSSG, AOSSG Survey: Accounting for Islamic Financial Transactions and Entities. Beijing: Asian-Oceanian Standard-Setters Group, 2011.

[56] R. Frankel, S. McVay, and M. Soliman, "Non-GAAP earnings and board independence," Rev. Account. Stud., vol. 16, no. 4, pp. 719-744, 2011.

[57] A. Maulana, "Determinan pengungkapan Islamic Social Responsibility Bank Islam: Analisis Lintas Negara," Universitas Indonesia, 2017.

[58] K. Septyan, "Analisis pengaruh karakteristik DPS dan KAP terhadap tingkat pengungkapan di bank syariah (analisis beberapa negara)," Tesis Progr. Pascasarj. Ilmu Akunt., 2014.

[59] A. A.-N. Abdallah, M. K. Hassan, and P. L. McClelland, "Islamic financial institutions, corporate governance, and corporate risk disclosure in Gulf Cooperation Council countriess," $J$. Multinatl. Financ. Manag., vol. 31, pp. 63-82, 2015. 